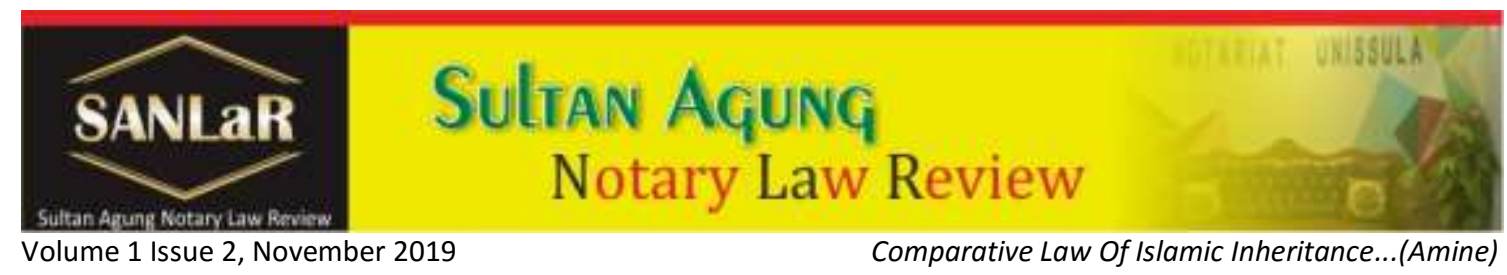

\title{
Comparative Law Of Islamic Inheritance And Civil Law Inheritance (West)
}

\author{
Amine El Khalfi ${ }^{1}$, Binti Fareha Moh. Zukri ${ }^{2}$ and Ong Argo Victoria ${ }^{3}$
}

Abstract. Talking inheritance law can not be separated from some of the elements that are bound. The elements are as follows: 1) The Heir, heir is the person who died or people who give so-called legacy heir. Usually heir bestows both wealth and debt obligations or to other persons or heirs. 2) The heirs, heirs are those who inherit referred to as heir was given the legal right to receive the assets and liabilities or debts left by the testator. 3) Treasure heritage, heritage is everything that is given to the heir to the testator possessed, whether it be right or property such as houses, cars, and gold as well as liability for the debt. Islamic law applies to the Indonesian people who are Muslims and under Article 171-214 Compilation of Indonesian law, the matter of Islamic law that is written in 229 chapters. In Islamic law the principle of inheritance bilateral individual, not collective and majority. But any differences with the inheritance law in Western, so this article will discuss about "Comparative Law Of Islamic Inheritance And Civil Law Inheritance (West)".

Keywords: Comparative Law; Inheritance; Islamic; Civil Law; West.

\section{Introduction}

Heritage comes from Arabic word that is Al-miirats, the Arabic language is a form of masdar (infinitive) of said waritsa-yaritsu-irtsan- miiraatsan. Meaning according to the language is the 'transfer of something from one person to another or of a nation to the other ${ }^{4}$. Inheritance is a matter that is important to your life. Not only for self, but also for your children and grandchildren someday. Despite its importance, is often the subject of this heritage be problematic. Not surprisingly, many people who dropped the ropes brotherhood because of inheritance. The main problems are usually due to disagreements about equality and fairness. Although the rules and the calculation is quite complicated. We need to think about it now and do not try to downplay this issue. It is feared about the inheritance will be big problems that arise in the future. For that, you need to learn the laws of inheritance in Indonesia. You also are required to know and understand. Thus, when there is division, will reach a consensus and the absence of disputes and waffle behind.

Elements of Inheritance, Talking inheritance law cannot be separated from some of the elements that are bound. The elements are as follows: 1) The Heir, heir is the person who died or people who give so-called legacy heir. Usually heir bestows both wealth and debt obligations or to other persons or heirs. 2) The heirs, heirs are those who inherit referred to as heir was given the legal right to receive the assets and liabilities

\footnotetext{
${ }^{1}$ International researcher from Marroco, e-mail: mohamad1995amine@gmail.com

${ }^{2}$ International researcher from Malaysia, e-mail: farehazukri@gmail.com

3 International researcher and International Peer reviewer International Islamic University Malaysia, e-mail: argovictoriaupin@gmail.com

${ }^{4}$ Ash-Shabuni. Muhammad Ali, 1996, Pembagian Waris Menurut Hukum Islam, Gema Insani Press, Jakarta, p.33
} 
or debts left by the testator. 3) Treasure heritage, heritage is everything that is given to the heir to the testator possessed, whether it be right or property such as houses, cars, and gold as well as liability for the debt.

Islamic law applies to the Indonesian people who are Muslims and under Article 171214 Compilation of Indonesian law, the matter of Islamic law that is written in 229 chapters. In Islamic law the principle of inheritance bilateral individual, not collective and majority. Thus the heir can be derived from the father or the mother ${ }^{5}$.

Civil inheritance law is often called western inheritance laws applicable to non-Muslim communities, including Indonesian citizen's descent, both Chinese and European provisions stipulated in the Civil Law (Penal Code).

With the above terms of inheritance law, contained a notion which includes the rules and principles which govern the process of transfer of property and the rights and obligations of a person who died. From the above can be seen a few definitions of several terms, namely: 1 . Heir is the person who passed away, leaving the wealth to others 2. Heirs: a person who is entitled to the assets / heritage 3. Hidden heritage: the wealth left behind in the form of assets and passive 4. Inheritance: the shift of wealth (rights and obligations) a person to the heirs. According to Hilman Hadikusumah, the term inheritance has two senses / meanings, namely: a. Forwarding means or the appointment of the heir when the heir is still alive b. From the above explanation will be discussed in more detail about the differences in Islamic inheritance and heir to the west $^{6}$.

\section{Research Methods}

This study use Legal Studies those are empirical and philosophical. Data were collected either obtained from Primary and Secondary Data Qualitative processed, as well as Inductive-Deductive. The data were analyzed using Doctrinal Approach.

\section{Result and Discussion}

\subsection{Islamic Inheritance Law}

\subsubsection{Islamic law:}

- Legal sources: the Qur'an, Hadith and ljtihad

- Inheritance system: Bilateral, Individual

- The inheritance because: their blood relationship, their marriage

- Religious differences did not inherit

- Heirs are only liable to the extent of inheritance

- Part boys and girls is 2: 1

- Part specific heir: $1 / 2,1 / 4,1 / 3,2 / 3,1 / 6,1 / 8$

- Child (grandchild) and the parents are not mutually close

\footnotetext{
${ }^{5}$ Apeldorn, L van, 1980, Pengantar ilmu Hukum (translation: Mr. Oetarid Sadino) Cet. XVI, Pradnya Paramita, Jakarta

6 A Pitlo, 1994, Hukum Waris Menurut KUHPerdata Belanda (translation: M.Isa Arief), Intermasa, Jakarta, p. 80
} 


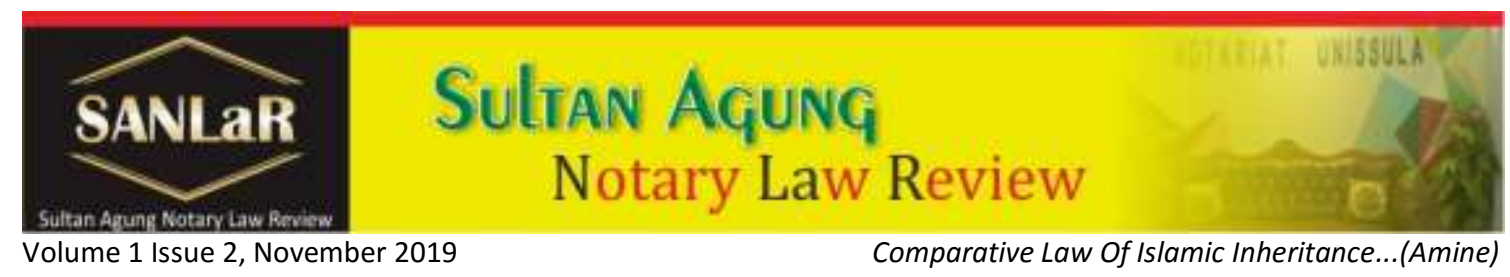

- $1 / 3$ of the maximum testamentary inheritance

- Marital property types: congenital treasure, treasure intervened.

\subsubsection{Inheritance law}

The main source of the Islamic Inheritance law is Al-Qur'an letter "women" An-Nisa" verse 11, 12, and 176 (Kalaalah). The Islamic Inheritance Law or Faraidh science is the science that is known. Who is entitled to inheritance and who is not entitled to, and also how the size for each heir ${ }^{7}$. Faraidh science including knowledge of the most noble level of danger, the highest position, the greatest reward, because of the importance, even the God who determines the proportion, He explained ration estate acquired by any heir, described mostly in a few verses are clear, for wealth and greed for the division is a human source, most of the estate is for men and women, big and small, the weak and strong, so there is no opportunity to argue her or speak with lust ${ }^{8}$.

\subsubsection{Dzawil Furudl}

Dzawil Furudl is a member of the family that owns the rights to inheritance of a deceased ${ }^{9}$ that is ${ }^{10}$ :

a. Man:

- Boys; Grandson of boys; Father; Grandfather / father's father; Siblings; Boys of brother; Husband; Uncle; The son of the uncle; Men who free a slave

b. Women:

- Girl; Granddaughter of the boys; mother; Grandmother; younger sister; Wife; The freeing of a slave woman

\subsubsection{Classification of Heirs}

There are three classes of heirs according to the teachings of bilateral:

a. Dhul faraaidh (commonly referred to as ashab furudh or dzawil furudh)

Dhul faraaidh is heir who has got a part for sure, that these parts have been

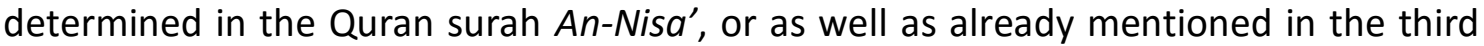
chapter Compilation of Islamic Law, which include ${ }^{11}$ :

- girls were not accompanied by men; mother; father in case there are children; widower; widow; brother in kalaalah; sisters, men and women joined bersyirkah in

\footnotetext{
${ }^{7}$ http//: Know Science Faraidhasysyariah.com

8 Pembagian Waris According to Islammedia.isnet.org

${ }^{9}$ Basic Inheritance in Islamslideshare.net

${ }^{10}$ Abdulkadir Muhammad, 1990, Hukum Perdata Indonesia, Citra Aditya Bakti, Bandung, p. ii

Djaj S. Meliala, 2015, Perkembangan Hukum Perdata Tentang Benda Dan hukum Perikatan, Nuansa Aulia, Bandung, p. 54-55

${ }^{11}$ Eman Suparman, 1985, Intisari Hukum Waris Indonesia, Armico, Bandung and see Hilman Hadikusuma, 1991, Hukum Waris Indonesia Menurut perundangan, hukum Adat, Hukum Agama Hindu-Islam, PT. Citra Aditya, Bandung, p. 321
} 
kalaalah; sister in kalaalah.

b. Dhul qarabat or residuary

Dhul qarabat is heir to inherit the remainder or not is determined, among them: boys; girls who accompanied men; father; brother in kalaalah; sister who was accompanied by brother in kalaalah

\section{c. Mawali}

Mawali is heir replacement that replaces a person to obtain an inheritance which had to be obtained by those who replaced it. Mawali is a descendant of the testator, heir brother offspring, or offspring of people who have some kind of agreement heir (e.g. a will) to the deceased.

Division :

- Half; Daughter, granddaughter of the boys, his half sister's mother, sister and husband had the same father if no children.

- Fourth; Her husband and children or grandchildren, wife without children or grandchildren of the boys.

- Eighth; Children or grandchildren joint wife of boys

- One third; Mother without children, the same mother Sister 2 or more.

- Two-thirds; Daughter, granddaughter of the boys, his half-sister's mother, his half sister

- One-sixth; the mother with a child or grandchild of a boy, grandmother, sister shared the same father his half-sister's mother, father with child or grandchild of a boy, Grandpa.

\subsection{Inheritance Law Civil}

Inheritance law in the science of law refers to the provisions laid down in the draft of Civil Code. Arrangements regarding the inheritance law can be found in article 830 to article 1130 of the Civil Code. However, an understanding of inheritance law itself cannot be found in the sound of the chapters set in the Civil Code. To find an understanding of the laws of inheritance then we will try to look at some understanding of the law of inheritance given by experts, as follows ${ }^{12}$ :

The law of inheritance according to Vollmar is a wealth transfer in full, which means the transfer of all rights and obligations of people who give or bequeath a legacy to those who receive an inheritance or heirs. The law of inheritance according to Pitlo is a set of regulations governing the law of the wealth because of the death of a person.

In general it can be said that the inheritance law is the law governing the position of wealth and properties of a person after death and set on the ways the transfer of wealth to others. In addition to the above-mentioned some sense, an understanding of inheritance law can also be seen in Presidential Instruction No. 1 of 1991, in Article 171 states that: Inheritance law is the law governing the transfer of property rights over

${ }^{12}$ Mariam Darus Badrulzaman, 1983, Mencari Sistem Hukum Benda Nasional, Alumni, p. 213 


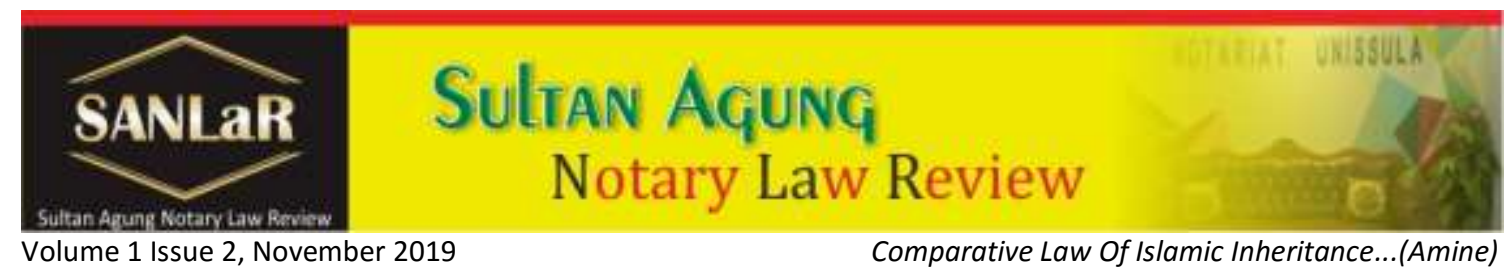

inheritance heir to then determine who has the right to be heir and determine what portion of each.

Civil inheritance law is often called western inheritance laws applicable to non-Muslim communities, including Indonesian citizens descent, both Chinese and European provisions stipulated in the Civil Law (Penal Code) ${ }^{13}$.

Civil inheritance law adheres to the individual system in which each heir acquire or own property inheritance according to their share. In the civil inheritance law there are two ways to pass on ${ }^{14}$ :

a. Pass under the laws or pass without a will is referred to as Ab-instentato, while the heirs called $A b$-instaat. There are 4 classes heirs under the law: Group I consists of husband and wife and children and their descendent; Group II consists of the parents and brothers and their descendent; Group III consists of grandparents and so on up; and Group IV consists of a family in a further lateral line, including brothers heir class III and his descendants.

b. Bequeathed by a will that someone be a statement about what he wanted after he had passed that by the manufacturer may be modified or revoked as long as he is still living in accordance with the Civil Code Article 992. How should the new will nullification or performed by a Notary,

Terms of making wills is true for those who are aged 18 years or older and already married, although not yet 18 years old. That belonged to the heir by a will is that everyone who is appointed by the testator by wills to become his heir.

Treasures switch, it must meet two requirements, namely:

a. General requirements:

- There are people who died (Article 830 of the Civil Code)

- There heirs abandoned (Article 836 of the Civil Code)

- There is a property that is abandoned (Article 1100)

b. Absolute requirement ${ }^{15}$

- There must be people who have died, but can occur in circumstances not present (470 in conjunction with Article 467 of the Civil Code) that the testator has not died.

- Void (van rechtswege) immediately, too, is known as the principle of le mort saisit le vif. This principle contained in Article 833 paragraph (1) of the Civil Code, abbreviated with the principle of the right to immediately saisine therefore also heirs left to demand that third parties who dominate inheritance so that the estate was returned to boedel heritage. This right is referred to as hereditatis petitio (Article 834 of the Civil Code).

- Wealth in the legal field property that is contained in books II and III of the Civil Code book, even though there are exceptions. While the rights and obligations

\footnotetext{
${ }^{13}$ Bandung Oemarsalim, 1987, Dasar-Dasar Hukum Waris Di Indonesia, Jakarta PNH, p.xi

${ }^{14}$ Simanjuntak, 2015, Hukum Perdata Indonesia, First edition, Kencana, Jakarta, p. 145

${ }^{15}$ R. Santoso Pudjosubroto, 1976, Hukum Warisan Di Indonesia, Wells Bandung, Jakarta, p. 43
} 
contained in the first book of the Civil Code does not switch, there are also exceptions.

Wealth (rights and obligations) that do not switch from books II and III of the Civil Code book is ${ }^{16}$ :

- The rights and obligations of the agreement granting authorization (Article 1792 of the Civil Code))

- The rights and obligations of the employment agreement or labor agreement (Article 1601 of the Civil Code a

- Membership of a partnership / company (Article 1646 of the Civil Code)

- Right to life forked interest (Article 1776 of the Civil Code)

- Usufruct (Article 756 of the Civil Code)

- There is the restriction, i.e. the right author for 70 years (Article 58 paragraph (1) in conjunction with a grain Company Act No.28 of 2014 concerning copyrights)

The rights and obligations of the switch from the first book of the Civil Code is the right of a child to deny the validity of Article 257 of the Civil Code). There are rights and obligations of Book I of the Civil Code which has a value of money but do not switch, favors as the right results (Article 311 of the Civil Code) and the right to alimony (Article 225 of the Civil Code).

\subsection{Civil Code of Inheritance}

Civil Code recognize two kinds of inheritance system, namely:

1) System inheritance $a b$ intestate (according to Law / for death / intestate)

2) System inheritance by a will (testament).

Inheritance nature of inheritance laws that apply in Indonesia until now still not a legal unification. The form and system of inheritance law is closely associated with familial forms of society and nature. While the systems of kinship to the people of Indonesia, have capital base of the system interesting bloodlines are basically three kinds of systems known descendants.

Forms of community and family properties located in Indonesia by descent system, namely:

- Patrilineal system / nature of fatherhood In principle the system of interest patrilineal lineage or grandfather/male line system in Indonesia there are the people in Tanah Gayo, Alas, Batak, Ambon, Papua, Timor and Bali.

- Matrilineal system / motherhood system fascinating lineage of female ancestors. Motherly familiarity in Indonesia there is only one area, namely Minangkabau

- System bilateral or parental / nature of father and mother, attractive good lineage through the father line or lines so that the mother in the family of this kind is essentially no difference between maternal and paternal: Java, Madura, East Sumatra, Whole Celebes, Ternate, Lombok, Riau, Aceh, and South Sumatra.

${ }^{16}$ Sri Soedewi Masjchoen Sofwan, Hukum Perdata Hak Jaminan Atas Tanah, Cet.Pertama, Liberty, Yogyakarta, p. 69 and see also Subekti, 1979, Pokok - Pokok Hukum Perdata, Cet, to. 14, PT. Intermasa, Jakarta, p. 241 


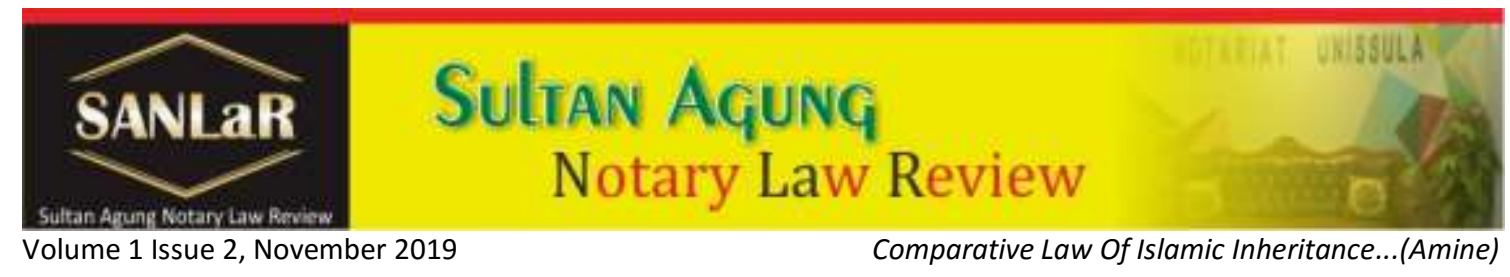

\section{Subjects of Inheritance}

1. Heir: a person who died and left property / wealth. Here is a prerequisite as the heir i.e. their rights and obligations to be met by a third party, which can be valued in money

2. Heirs:

a. Heir by his own position (uit eigen hoofed) or inherit directly, for example, if the father dies, the children all appeared as heir. According to the Civil Code, the heir apparent classification, are ${ }^{17}$ :

- The first group, namely children and their descendent in a straight line down. Starting in 1935 the right to inherit the husband or wife who lived the longest likened to a legitimate child (Article 852a of the Civil Code)

- The second class, parents and brothers heir; in principle part of parents equated with brothers heir part, but there is no guarantee where part of parents should not be less than a quarter heritage

- The third group, Article 853 and Article 854 of the Civil Code, in which case there is no goal. First and goal. Second, the legacy should be divided into two (kloving), half of his paternal grandparents, and once again for the grandparents of maternal

- The fourth group, the testator's relatives in the line deviates to the degree to six.

b. Heirs based reimbursement (bij plaatsvervulling), also known as indirect heirs (grandchildren heir)

- Substitutions in a straight line down, Article 848 of the Civil Code: only those who have died only to be replaced

- Substitutions in line to the side, each sibling / step-deceased first replaced by his son all

- Substitutions in the side line, also involves the replacement of the household of a further, for example, uncle / nephew, if predeceased replaced by derivatives

c. Third parties who are not heirs can enjoy the treasures, in this case the possibility arises because there is a provision of the Civil Code a third party who is not an heir, but can enjoy the legacy heir by a testament / will ${ }^{18}$.

4. The third party involved in the inheritance addition heir and the heir in the Civil Code, also known as the ${ }^{19}$ :

- A comis fidei, is a legacy of giving to someone heirs provided that he is obliged to keep that heritage and after the passage of time, it should be left pad heritage of others. How demise of this kind by the Act referred to as the demise in stride

- Executeur testamentair, implementation will appointed by the testator, which is tasked with overseeing the implementation of wills in earnest in accordance with the will of the testator

\footnotetext{
${ }^{17}$ Supomo, 1993, Bab-Bab Tentang Hukum Adat, Pradnya Paramita, Jakarta, p. 37

18 R. Subekti, R. Tjitrosudibio, 1999, Kitab Undang Undang Hukum Perdata Terjemahan, PT.Pradnya Paramita, Jakarta, p. 120-121

${ }^{19}$ Wirjono prodjodikoro, 1966, Hukum Warisan Di Indonesia, Well, Bandung, p. 98
} 
- Bewindvoerder / manager, a person specified in the will to take care of riches, so that the heirs / legataris only receive revenue from the legacy property. It is intended that such property should not be spent in a short time by heirs / legataris.

5. Rights and Responsibility heir and the heir

a. Rights and obligations of the testator

1). The right heir, raised before the opening of the inheritance within the meaning of the heir dies before the right said his will in a testament / testament, which include:

a) Erfstelling, an appointment of one / some people become heirs to get most or all of the inheritance (testamentair erfgenaam: heirs according to a will)

b) Legaat, granting the right to an individual on the basis of a testament / special testament, which include: Rights to one / or more specific objects; The right of all of the kinds of specific objects; Vruchtgebruik rights, of part / whole heritage (Article 957 of the Civil Code) People who receive Form legataris called legaat testament:

- Open baar testament, testament made by a notary in the presence of two witnesses

- Olographis testament, testament written by the heir himself, then handed over to a notary to be stored in the presence of two witnesses

- The secret Testament, made by the heir not be written by hand, and testament to be sealed and submitted to a notary in the presence of four witnesses

2) Obligations heir is a limitation on the right are stipulated by the Law. He should heed their legitieme portie, that a certain portion of the treasures that cannot be waived by the person who left a legacy (Article 913 of the Civil Code).

b. Rights and obligations Rights heirs, after the open of inheritance, the heirs are entitled to determine the attitude ${ }^{20}$ :

1) To receive the full, which can be either expressly or otherwise. Strictly speaking, if the revenue is put forth in a deed which contains his acceptance as an heir. Secretly, if the heirs of the acts of acceptance as heir and actions should reflect the acceptance of the legacy, namely by taking, sell or pay off debt of heir

2) Accept with reserve, (right to exchange). Voorrecht van boedel beschijving or annvaarding. The beneficiare of this should be stated at the District Court Clerk in open place. The Impact of most important legacy of heritage in beneficiare this is an obligation to pay the debts of other and load the testator is limited such that repayment is limited by the power of inheritance, in this case means that the heirs do not have to bear the debt with its own wealth, if the debt is greater than the heir to his property

6. Rejecting heritage, it is possible, if the amount of assets in the form of debt obligations outweigh the right to enjoy the treasures. Rejection shall be carried out with a statement to the local District Court Clerk.

20 https://id.wikipedia.org/wiki/Hukum_waris\#cite_note-Ilmu_Faraidh-5, accessed on $5^{\text {th }}$ November, 2019 


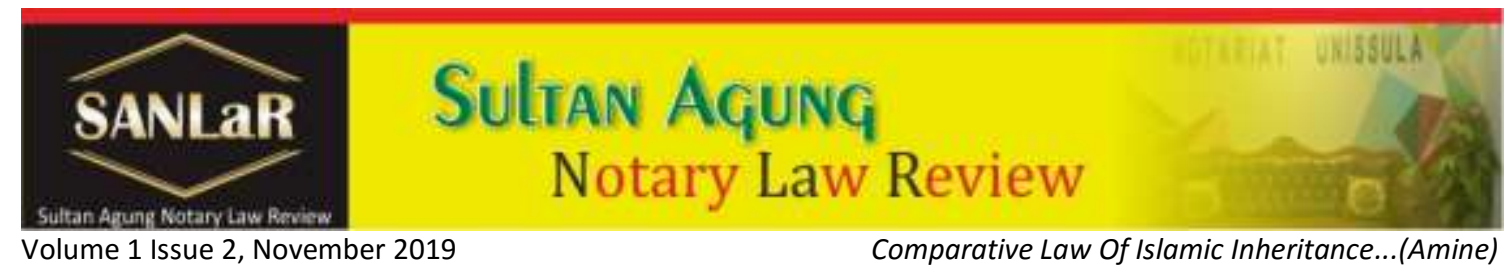

Liabilities heir:

- Maintaining the integrity of the treasures before the inheritance is divided

- Finding a way division in accordance with the provisions etc.

- Pay off debt heir if the testator in debt

- Carry out a will if there is

- The division of inheritance

Article 1066 of the Civil Code specify / content can be inferred:

- Not an heir who could be forced to let the estate is not divided

- Allocation the estate can be divided anytime

- Opened the possibility to defer the division of inheritance with a period of 5 years, this time limit may be extended another 5 years with less approval a heir

Civil Code does not specify a particular way of inheritance, if the heirs competent to act on its own and everything is in place (present) when allocation heritage then the division of the inheritance left to their own, but in case there among heir children minors or anyone placed under curatele (guardianship), then the inheritance should be done with a notary deed and before Wees kamer (heritage agency) ${ }^{21}$.

Inbreng namely restoring objects into boedel. This problem arises if it turns out the testator during his lifetime has given it schenking objects to the temporary heir regarded as a top voorschot section to be calculated later.

According to the Act are required to do inbreng are the heirs in a straight line down, with no difference whether inherit in full or accept the notes, but the heir is entitled to determine that the heirs who have received gifts during life freed from inbreng 's heir $^{22}$.

The nature of regulation differs from rules legitieme inbreng protie: to protect the interests of the heirs who have relationship with the heir thus meeting the regulations of coercive means can not be ruled out. Someone who never received the gift of life when things do not need to do inbreng if he is not an heir, he can only be prosecuted if the reduction of the abuse turns giving legitieme portie. 13 clauses 1079 of the Civil Code, the division of inheritance ${ }^{23}$ :

a. Each expert receive certain goods with price / equal value such as half the inheritance if the heir only consisted of two people, one-fifth if the heir is composed of five people, this will continue.

b. If there is among heirs who received the goods / estate more than its parts, on the other hand between the heirs receive less than the share of the heirs who receive section required to provide a certain amount of cash in that gets less than its share

${ }^{21}$ cermati.com/artikel/pengertian-dan-ragam-hukum-warisan-di-indonesia, accessed on $5^{\text {th }}$ November, 2019

${ }^{22}$ https://id.wikipedia.org/wiki/Warisan\#cite_note-1, accessed on $5^{\text {th }}$ November, 2019

${ }^{23} \mathrm{http} / / /$ www.negarahukum.com/hukum/hukum-waris-islam-di-indonesia.html, accessed on $5^{\text {th }}$ November, 2019 
If there is a dispute about who among those who got a specific item as a part, then it is should lottery. If there is no agreement on the determination of certain goods to be distributed to each of the heirs then be requested court decision after receiving the determination of certain goods, Article 1080 of the Civil Code opens the possibility of exchanging part of each among the heirs of Article 1083 Civil Code states: heritage if division has occurred.

7. Object In principle object of inheritance law, inheritance law is property that is transferred from the heir to the heir, which can be:

a. Assets, a real thing existing and / or in the form of bills / debts to third parties. In addition the assets may be immaterial rights such as copyrights, patents etc.

b. Liabilities, a debt that must be repaid to the heir to a third party, as well as other liabilities (save somebody else) So the object of inheritance law is a property that can be concrete objects and intangible, which means the rights and obligations heir born of the legal relationship the family can not be inherited, unless the right of the husband / father to deny his son

\section{Legitieme portie}

Is a part of a particular heritage which must be received by the heirs of the estate heritage that can not be contested. Entitled to receive / acquire heirs in a straight line, either downwards or upwards. And only arise when one is in a state truly came to the fore as the heirs according to law. In this case there is a priority / closing, her missal if the testator dies leaving children and grandchildren as heirs of the first class, the parents as heirs and are therefore not entitled to a legitieme portie.

A person who is entitled to legitieme portie called legitimaris. He can ask for cancellation of each testament that violated his right and he is entitled to demand that also held reduction (inkoeting) against all kinds of demise, either in the form or in the form of legaat erstelling which reduces their rights.

Regulations regarding legitieme portie by law be regarded as a restriction on the right heir in making a testament to the will of his own. Because the chapters about legitieme portie was included in the section on the right to inherit under a will (testamentair erfrecht)

\section{Unkempt heritage treasure}

When the estate was open but no one heir to the fore as heir, no one has refused the inheritance, then inheritance is considered as inheritance are not neglected. In this case, without waiting for the judge's order, Hall Heritage shall take care of these treasures. Maintenance jobs that must be reported to the local District Attorney. If there is a dispute about whether a legacy considered neglected or not, this determination will be decided by the judge

Task Heritage Hall (BHP).

1) Shall make or inventory details about the state of the treasures, which was preceded by the sealing of goods. 


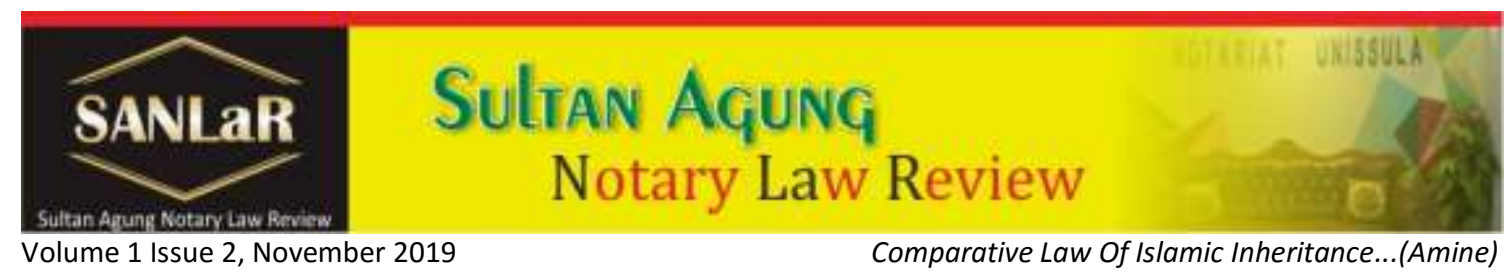

2) Mandatory clearing heritage, within the meaning of the heir to collect receivables and pay all debts of the testator, if requested by the authorities. BHP also required to provide accountability.

3) Must call the heirs may still exist in a newspaper or call other authorized If within a period of three years commencing halted at the time of opening of the inheritance, still there was no heirs come forward, BHP will give an account of the maintenance of it to the State, the next treasure the relics will be inherited and become the property of the State.

10. Heirs who do not deserve to inheritance

Act says there are four things, one not worthy heirs, namely:

- An heir to the verdict has been convicted of killing blamed or at least try to kill the heir

- An heir to the verdict has been punished for slander and denounce blame the heir, that heir maligned commit crimes punishable by four years or more jail

- Heirs who with violence has obviously hinder or prevent the testator to make or revoke a will

- An heir who had embezzled, gutted, and falsified wills heirs If it turns out that this should not control most or all of the treasures and he pretended as heirs, he must returns all under their control, including the results of which have enjoyed

\section{Closing}

Indonesia has two Inheritance law, they are based on Islamic law (Faraidh) and Civil Law (Penal Code). Every Indonesian people can choose one of them. Muslims in Indonesia who want to implement the Islamic law let privately implement it under Islamic Law Compilation 1991 at Islamic Court. And for another party can use the Civil law at State court. So generally inheritance by the heir to the heir should be accepted gracefully and sincerity. It is the duty of the Ministry of Religious Affairs, Indonesian Ulema Council (MUI), the Institute of Islamic Education, Islamic organizations such as Nahdlatul Ulama (NU), Muhammadiyah and CBOs which has a base period of extensive as Bamus Betawi to socialize and give teaching inheritance law of Islam, in order to Indonesian people know and understand then the allocation/division of inheritance.

\section{Reference}

[1] Apeldorn, $\amalg$ van, 1980, Pengantar ilmu Hukum (translation: Mr. Oetarid Sadino) Cet. XVI, Pradnya Paramita, Jakarta

[2] A Pitlo, 1994, Hukum Waris Menurut KUHPerdata Belanda (translation: M.Isa Arief), Intermasa, Jakarta

[3] Abdulkadir Muhammad, 1990, Hukum Perdata Indonesia, Citra Aditya Bakti, Bandung

[4] Djaj S. Meliala, 2015, Perkembangan Hukum Perdata Tentang Benda Dan hukum 
Perikatan, Nuance Aulia,

[5] Bandung Eman Suparman, 1985, Intisari Hukum Waris Indonesia, Armico, Bandung

[6] Hilman Hadikusuma, 1991, Hukum Waris Indonesia Menurut perundangan, hukum Adat, Hukum Agama Hindu-Islam, PT. Citra Aditya, Bandung

[7] Mariam Darus Badrulzaman, 1983, Mencari Sistem Hukum Benda Nasional, Alumni,

[8] Bandung Oemarsalim, 1987, Dasar-Dasar Hukum Waris Di Indonesia, Jakarta PNH

[9] Simanjuntak, 2015, Hukum Perdata Indonesia, First edition, Kencana, Jakarta

[10] R. Santoso Pudjosubroto, 1976, Hukum Warisan Di Indonesia, Wells Bandung, Jakarta

[11] Sri Soedewi Masjchoen Sofwan, Hukum Perdata Hak Jaminan Atas Tanah, Cet.Pertama, Liberty, Yogyakarta

[12] Subekti, 1979, Pokok - Pokok Hukum Perdata, Cet, to. 14, PT. Intermasa, Jakarta

[13] Supomo, 1993, Bab - Bab Tentang Hukum Adat, Pradnya Paramita, Jakarta.

[14] R. Subekti, R. Tjitrosudibio, 1999, Kitab Undang Undang Hukum Perdata Terjemahan, PT.Pradnya Paramita, Jakarta

[15] Wirjono prodjodikoro, 1966, Hukum Warisan Di Indonesia, Well, Bandung

[16] https://id.wikipedia.org/wiki/Hukum waris\#cite note-IImu Faraidh-5, accessed on $5^{\text {th }}$ November, 2019

[17] cermati.com/artikel/pengertian-dan-ragam-hukum-warisan-di-indonesia, accessed on $5^{\text {th }}$ November, 2019

[18] https://id.wikipedia.org/wiki/Warisan\#cite note-1, accessed on $5^{\text {th }}$ November, 2019

[19] http://www.negarahukum.com/hukum/hukum-waris-islam-di-indonesia.html, accessed on $5^{\text {th }}$ November, 2019

[20] Civil Law (Penal Code)

[21] Islamic Law Compilation of 1991. 